\title{
Aspects of irrigation development in the Netherlands East Indies
}

\author{
MAURITS W ERTSEN ${ }^{*}$
}

\begin{abstract}
The 'Romijn' discharge measurement structure was developed in the Netherlands East Indies. By the end of the colonial period in the 1930s, it had become the standard structure in irrigation. The Romijn design is not only still the main discharge measurement structure in Indonesia, it is also used in Dutch water management practice and education. The question of continuity is at the heart of concepts such as 'technological tradition' or 'technological regime', and this continuity links the information embodied in a community of practitioners with the hardware and software the members master. Such communities define accepted modes of technical operation. Engineering education is an important mechanism in preference-guided selection of design solutions, and obtaining an engineering degree is much like passing the preparatory requirements for community membership. When, in 1967, a civil engineering student from Delft Polytechnic presented his final paper for an irrigation design to his supervisors, the first question they asked was why he had not used a Romijn weir as an off-take structure. The Dutch irrigation regime, which consists of the explicit and implicit rules of Dutch irrigation design, is the central subject of this paper. In this paper I shall discuss two related issues: (1) how the Netherlands East Indies irrigation regime developed, and (2) how the (dis)continuities in irrigation education and practice following Indonesian independence can be understood. Naturally, while discussion of these issues, to a certain extent at least, depends on the data available, it also depends on the researcher's perspective.
\end{abstract}

\section{Introduction}

One day in 1967 a civil engineering student in the Department of Civil Engineering of Delft Polytechnic presented to his supervisors his final paper in engineering design for an irrigation system. One of the first questions the supervisors asked him was why he had not used a 'Romijn' weir as secondary off-take structure in his design. This Romijn structure was developed in the Netherlands East Indies at the

\footnotetext{
* Water Resources/Water Management group, Department of Civil Engineering and Geosciences, Delft University of Technology, P.O. Box 5048, 2600 GA Delft, The Netherlands, Stevinweg 1, Delft, tel. + 31 (0) 1527 87423, fax + 31 (0) 1527 85559, http://www.wrm.tudelft.nl
} 
end of the colonial period, and by the 1930s it had become the standard structure used in new irrigation schemes. This student's experience is only one example of the persistence of Netherlands East Indies irrigation and drainage design practices in civil engineering education in Delft. The artefact in question, the Romijn weir, also persists. It is not only one of the main discharge measurement structures still used in Indonesia, but it is also used in Dutch water management practice. The Horizontal Broad Adjustable Weir (Hobrad) is a modified Romijn weir; it dates from the 1970s, when drinking water supply activities in a Dutch province required a structure that could measure and regulate discharges with little head losses (not over a few decimetres) (figure 1). ${ }^{1}$

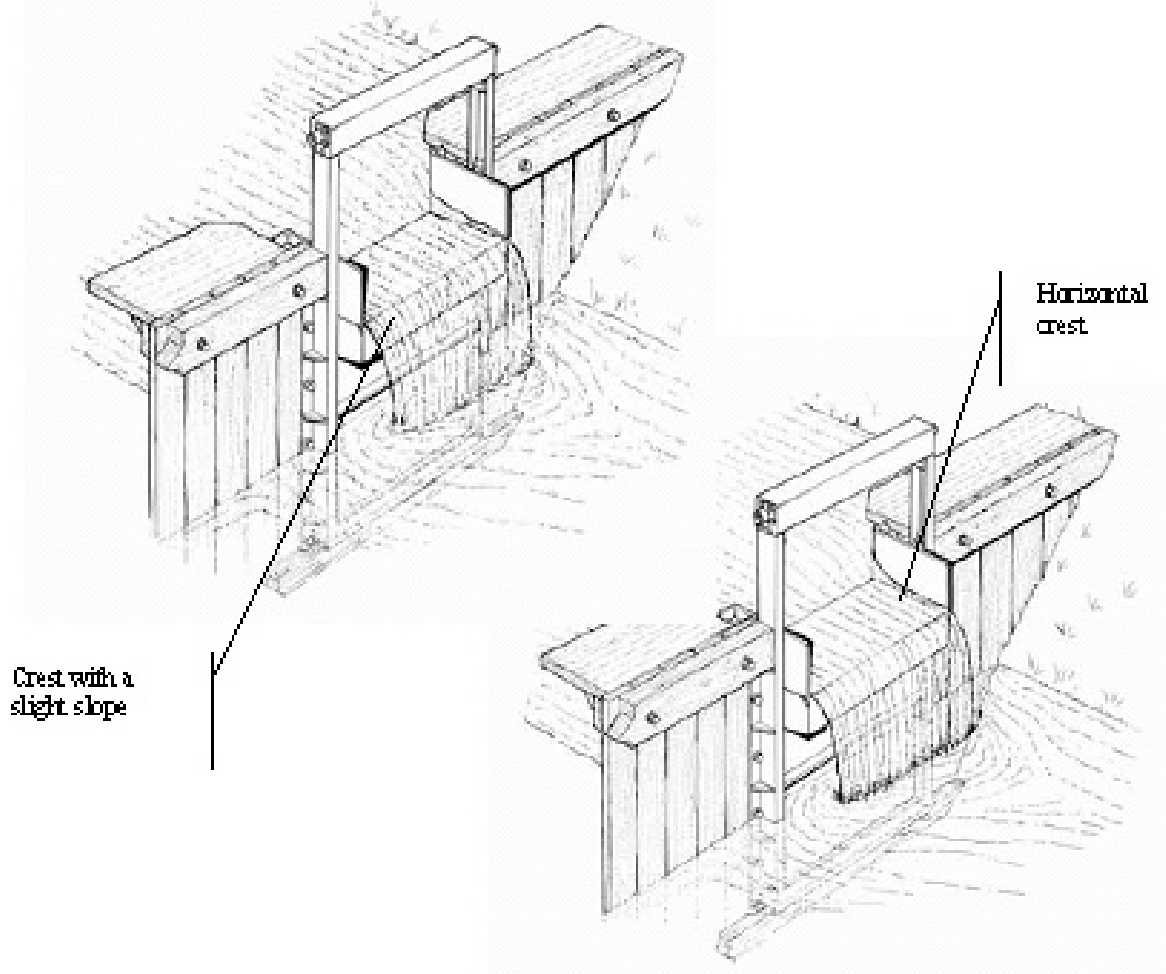

Figure 1 Romijn (upper left) and Hobrad (lower right) weirs ${ }^{2}$

Such apparent persistence in Dutch irrigation practice and education was the main inspiration for this paper. ${ }^{3}$ The idea of persistence in engineering practice is not new. 
Technological knowledge comprises traditions of practice, which are properties of communities of technological practitioners. Technological traditions of practice comprise complex information physically embodied in a community of practitioners and in the hardware and software of which they are masters. Such traditions define an accepted mode of technical operation, the conventional system for accomplishing a specified technical task. Such traditions encompass aspects of relevant scientific theory, engineering design formulae, accepted procedures and methods, specialised instrumentation, and, often, elements of ideological rationale. ${ }^{4}$

Engineering education is an important mechanism in this process of preference-guided selection of design solutions. Obtaining an engineering degree is much like passing the preparatory requirements for community membership. The question of continuity is at the heart of the concept of 'technological tradition'5 or 'technological regime'. ${ }^{6}$ The regime concept aims to overcome the difference between internal and external positions, and recognises that

invention and innovation are conditioned by such factors as earlier innovations, the search heuristics of engineers in an industry, available technical knowledge, market demand and industrial structure. ${ }^{7}$

Since the regime concept bridges the gap

[b]etween the formalised knowledge that can be traced through courses and treatises, and the everyday decisions made by engineers, there must be for sure some kind of intermediate know-how. ${ }^{8}$

The intermediate know-how, the rules structuring 'how and what to do' are included in the regime concept. The Netherlands East Indies irrigation regime, consisting of explicit and implicit rules for irrigation design, is the central subject of this paper, in which I shall explain two related issues: (1) how the Netherlands East Indies irrigation regime developed, and (2) how the (dis)continuities in irrigation education and practice following Indonesian independence can be understood. Naturally, discussion of these issues, to a certain extent at least, depends on the data available. It also depends on the researcher's perspective. When analysing technical rules, decisions, or practices over a certain period, it is possible to emphasise similarities or differences over time; that is, the focus can be on continuities or discontinuities in regime development. I prefer to start from a relatively narrow definition: to analyse the development process of the Netherlands East Indies irrigation regime by focusing on rules that structure the activities of actors involved in its development. More specifically, I am interested in those actions, discussions, and positions of Dutch irrigation engineers that shaped their irrigation design approach.

\section{Continuity, discontinuity, and technological regimes}

Continuity may be at the heart of the regime concept, but many researchers have studied technological regimes as a way to describe technological change or transitions. ${ }^{9}$ These studies explain changes in technological 
development, or shifts from a particular technology to another type, by referring to the structural environment a regime offers. While there is no 'change' without 'persistence', change would be measured against a background of non-change or persistence. Change and persistence both exist in worldwide irrigation development; schools of irrigation, or regimes, still influence irrigation practice. Our model student was confronted with the colonial design school. Engineering education, which transfers existing knowledge and design rules to new engineers who have no direct link with the practice in which the rules were developed, can be considered a structuring element of the mind. Another such a structuring element of the mind, closely related to education, can be found in engineering handbooks. Successful approaches become examples, even blueprints, for technological design. Selected examples are presented to students at engineering schools. The professional engineering organisations, including educational institutions as well as Departments of Irrigation (or generally, Public Works), select, discuss, and promote successful technological solutions. Gradually, a tradition develops. A key term here is 'gradually', because studying technological change and trying to identify shifts of only a few years' duration is not very fruitful. Geels studied technological change over a longer time-frame, on the order of 70 to 100 years. ${ }^{10}$ There, change and persistence not only become difficult concepts, but may not even be applicable. Studying such long periods is like studying social change:

\begin{abstract}
"Continuity" is actually a more useful term by which to examine the relation between stability and change in society than words like "persistence" are: for continuities exist through the most radical and profound phases of social transformation. ... 11
\end{abstract}

The extremely simplified description of regime development given above still has some functional connotations. Such a description obviously does not provide a better understanding of development and maintenance of technological regimes. Functionalism is the last thing I would want to defend; human beings, not abstractions or 'forces', created the irrigation works and knowledge in the Netherlands East Indies. I am much more interested in conceptualising technological traditions in the way Giddens discusses the concept of structure:

\footnotetext{
"Structure" refers to "structural property", or more exactly, to "structuring property", structuring properties providing the "binding" of time and space in social systems. . . . [t] hese properties can be understood as rules and resources, recursively implicated in the reproduction of social systems. ${ }^{12}$
}

Structures do not exist; they are manifested through the constituting moments of social systems. This

implies recognising the existence of: (a) knowledge - as memory traces - of "how things are to be done" (said, written), on the part of social actors; (b) social practices organised through the recursive mobilisation of that knowledge; (c) capabilities that the production of those practices presupposes. 13 
Technological regime development is a two-way process between structures and actors. Inspired by Giddens' propositions and guided by Van de Poel, ${ }^{14}$ I define a technological regime as a set of rules that structures activities of actors (engineers) involved in development and use of a particular technology (irrigation). These rules can vary in form and content. Some are related to the design of technologies, others to use, still others to divisions of labour or roles.

Some rules will be explicitly laid down in requirements and technical norms. Other rules will be tacit and implicit and will be followed by the actors on the basis of habits or tacit knowledge... Rules in technological regimes can also be embodied in production apparatus or technological artefacts. ${ }^{15}$

The totality of the relevant rules shapes the technological regime. Within a technological regime different categories of rules can be ordered hierarchically (figure 2); I employ five of these categories. Together, these five categories shape the irrigation regime; they represent the information, hardware, and software relevant for the community of irrigation engineers.

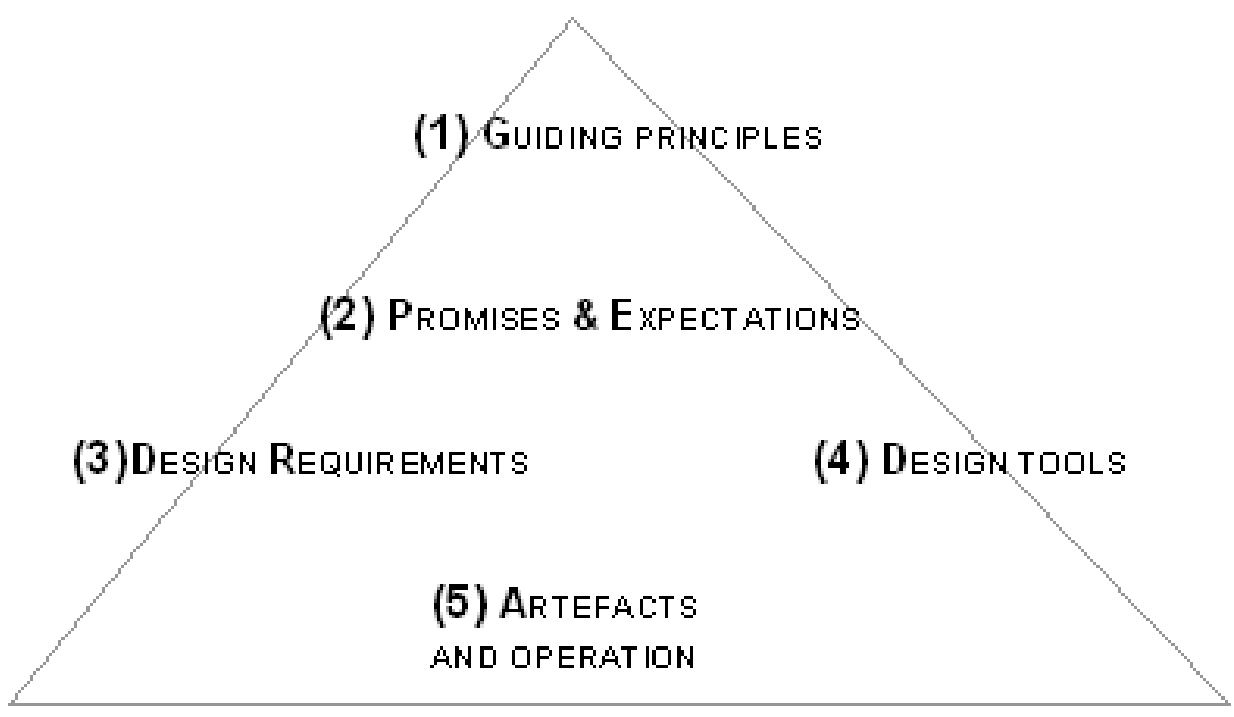

Figure 2 The technological regime triangle ${ }^{16}$

The basic premises were coined by Van de Poel. These include:

1. 'guiding principles', which link the design of a technology to doctrines and values that are used to legitimise a tradition and its outcomes. Closely related to these principles are

2. the 'promises and expectations' about a future technology, which will be translated into more specific requirements for new technology. I use the term 
3. 'design requirements' to integrate the categories of 'design criteria' and 'requirements and specifications' used by Van de Poel. Both his terms define the kind of functions to be fulfilled by an artefact and the kind of boundary conditions that are important in the design of a technology. To enable fulfilling the requirements,

4. 'design tools' are employed, including scientific knowledge, design heuristics, technical models, and formulas, design methods, and approaches. Moreover,

5. the category 'artefacts and operation' includes the result of any design activity; both as physical objects (canals, structures) and in the operation and management procedures (water distribution regulations). Artefacts should not be considered rules, as they only fulfil functions and must meet design criteria and requirements. On the other hand, artefacts contain (many) implicit rules used in the further development of a technology. They can and certainly do function as exemplars: future designers still apply them because they are known or have been proven in practice. Our civil engineering student experienced the power of the typical exemplar.

The categories are structured in a hierarchy; guiding principles are on a 'higher level' than 'design tools'. In the Netherlands East Indies context, 'higher level' not only refers to the more abstract nature of guiding principles, in contrast to, for example, design tools, but also to the larger number of stakeholders involved in formulating guiding principles (as well as in the political connotation of such activities). Debates on water regulations involved civil servants and engineers, government and private industry. Discussions about which structure performed best to realise water distribution were exclusively situated within the civil engineering circle. Higher level rules determined whether lower level rules, such as design tools and artefacts, were appropriate: to understand the development process of the artefacts, it needs to be linked to the general discourse on water regulations. Debates on artefacts within engineering circles, however, do not refer to political-economic discourse.

\section{Irrigation development in the Netherlands East Indies ${ }^{17}$}

When the predecessors of our modern irrigation engineers arrived on Java, they found people who made a living from farming, either rain-fed or irrigated. From early times irrigation technology has been an important factor in the expansion of wet rice farming on sawahs in the Indonesian archipelago. In the beginning the Dutch were impressed with Indonesian irrigation technologies and results, but this soon changed. The engineers stressed that the (larger) indigenous irrigation structures had to be seen as unsatisfactory. Of course, it was in their interest to do so, given their 
relatively weak position in the early colonial state. Developing engineering irrigation was an important instrument in the emancipation of engineers in the colonial bureaucracy. Irrigation systems were (and are) constructed to achieve certain goals: they were the material translation of colonial production and water management principles.

The colonial engineers were trained in the Dutch water tradition; they were experienced in the struggle against water. But short of confronting the engineers with severe drainage and flooding problems, the East Indies context demanded a struggle for water quite different from that in the mother country. In this respect the engineers had to start pretty much from scratch. The learning process of Dutch irrigation engineers in the East Indies, their struggle with a foreign environment, resulted in the establishment of new design rules and the development of new knowledge. A colonial irrigation technological regime developed over time. Especially in the first half of the nineteenth century the 'permanent' engineering structures were destroyed or seriously damaged by 'bandjirs' (flash floods) as quickly as were the indigenous 'temporal' structures.

The establishment of the Bureau of Public Works in 1854 was a political recognition of the potential role of engineers and technical support in colonial irrigation development: one main task of the Bureau was to construct irrigation works on Java. The engineers remained subordinate to the civil service, however; the 'Resident' (administrative representative of the civil service on the regional level) usually took the initiative for irrigation development. Civil servants did not always call for help from the engineers, however. Furthermore, the Bureau had to cope with a lack of financial resources and personnel, and even in cases where civil servants required support, the Bureau could not always provide it. Not many projects were realized before 1890. The quality of these projects did improve, however, indirectly strengthening the position of engineers. Engineers succeeded in better understanding and controlling the (natural) environment in which they had to design and construct.

Colonial irrigation activities were initially intended to support the European sugar cane cultivators in the nineteenth century, but later efforts were extended to supporting and improving the rice cultivation methods of the indigenous population as well. In the period from 1830 to 1870 , Javanese farmers had to cultivate certain cash crops as part of the 'Cultivation System' ('Cultuurstelsel'). This system was introduced by Governor General Van den Bosch in an attempt to make the colony profitable following the Java War (1825-1830). Two of the crops to be cultivated needed irrigation: sugar cane and (to a lesser extent) indigo. Sugar cane, the most important irrigated commercial crop by far, was grown in Eastern Java. In the 1840s and 1850s several famines occurred on Java, and colonial policy also began to include support for rice farming through irrigation development. Commercial crops were grown in the same areas and on the same fields as those used for rice. The commercial 
agricultural enterprises did not own land, as they would have done in a plantation system, but rented land from the Javanese farmers. Thus, even in the early colonial irrigation efforts, irrigation systems in the East Indies had to irrigate both sugar cane and peasant crops (mainly rice in the wet West Monsoon between October and March/April and dry crops ('polowidjo') in the dry East Monsoon). Water had to be distributed to all these crops through the same canal system. Therefore, water distribution methods were designed to divide (distribute and measure) the water between commercial and food crops in a just way.

Following a period of discussions (concentrated around the turn of the nineteenth century) about what exactly 'just' meant and how it could be achieved, a centralized water management system developed, with engineers in charge. Co-existence of peasant crops (rice, and in the East Monsoon the non-irrigated crops known as polowidjo) with the commercial crop, sugar cane, in the Javanese irrigated areas has been a determining factor in Dutch colonial water management (guiding principle). Sugar cane was an important irrigated crop from the very beginning of the Cultivation System; sugar estates were the sugar producers in the East Indies. The estates did not own the land on which the sugar cane grew, but they rented it for a period of three years from the peasant owner. ${ }^{18}$ Otherwise, rice was usually grown on these lands in the West Monsoon. As sugar factories rented new land every year, each year different sawahs were chosen to plant with sugar cane. Rice and sugar cane were irrigated, but not according to the same rhythm: rice needed irrigation water in the West Monsoon, whereas sugar cane needed most of its irrigation water in the East Monsoon. For further details on water distribution patterns, see below. What matters here is that: (1) in general the irrigation infrastructure on Java had to irrigate both sugar cane and rice, and (2) that the relative amount and location of sawahs planted with these crops changed over the years. Later on water was distributed to rice and sugar cane separately, but using the same canal system. Apparently, the custom of allowing sugar cane to be irrigated during the day in the East Monsoon meant that peasant crops had to be irrigated at night (or from late afternoon onwards). This custom had its origins in the Cultivation System. Water distributed to sugar cane was measured with movable measuring weirs immediately before the water entered the field(s). The above description reveals the two basic requirements of East Indies water management: (1) water measurement (although in the beginning only for sugar cane), and (2) the need to adjust water distribution daily and annually. ${ }^{19}$

In 1885 a new regulation for the Bureau of Public Works was introduced; the Bureau became independent of the general civil service. The new Department of Public Works, which had general and regional offices, became the centre of irrigation activities. The residents controlled only the small regional offices, but it was the general office that included the 'Irrigation Brigade'. This brigade, which was merged a few years later 
with the existing Technical Unit, was charged with conducting research on the possibilities for providing all governmental areas with modern irrigation facilities. In 1890 the General Irrigation Plan for Java defined 19 irrigation projects to be developed; other projects were included in 1907. Most of these projects were located in East or Central Java. As part of these projects several regulations were developed to define procedures for allocating and distributing irrigation water to various crops and use(r)s. Although local management arrangements to distribute water had already existed, they were often not written down. The Dutch civil service was only required to deal with them if there were problems. In 1893 a test carried out on two small irrigation systems on Eastern Java was intended to provide experience with proper, standardised colonial water management on an irrigation system level. Both these schemes, the Pekalen and the Pategoean systems, were relatively small compared with the systems designed and exploited from 1895 to 1900 . Unlike many of the new systems, both of these were improved versions of Javanese systems, and both were located in hilly or mountainous areas. In contrast, later engineering irrigation systems were usually located in the extensive coastal plains of Northern Java. Therefore, the irrigation environment of the experiments may no longer have been very representative of newer systems, and the governmental decision in favour of the Pategoean experiment may not have matched daily practice for the majority of new irrigation systems. The Pemali system was the main example of the new systems (its irrigated area was about 45000 bouw). The Pemali water distribution methodology set the standard for water regulation in the East Indies.

In 1901 an Ethical Policy introduced new welfare measures to improve conditions for the Javanese population, which also led to Javanese agriculture receiving increased attention. As a result, agricultural experts from the Department of Agriculture (established in 1905) entered on the irrigation scene. Irrigation was an important instrument in the welfare approach. The option to import rice for the growing population also became an issue. Irrigation efforts continued as part of the General Plan. Not everything the irrigation engineers did was successful, however. The irrigation plans in the Solo Valley proved to be overly ambitious. These plans were developed as part of the projects to divert the river's estuary away from the Surabaya area to the Java Sea to prevent sedimentation of the Surabaya waters. The plans included a canal to Surabaya to be used for transportation and drinking water. This canal could also irrigate more than 200,000 bouws (a bouw equals 0.7 hectare). The entire system would consist of a $165-\mathrm{km}$ main canal and $900 \mathrm{~km}$ of smaller canals. At the end of the nineteenth century it became clear that the project costs were much higher than the budget would cover; it was suspended in 1898 , and cancelled altogether in 1903. The abandonment of the Solo project was a source of great consternation among the Dutch engineers, and 
was perceived as showing a lack of confidence in engineering irrigation activities.

The planned works of the General Irrigation Plan, however, were continued. The irrigation engineers could point to several successful projects: one was the Pemali system. Its design process as well as water management procedures and regulations have become the standard model for irrigation development in the East Indies. In the early 1920s, after the General Irrigation Plan had been realised and colonial policies returned to normal following the First World War, a new set of irrigation projects was defined. The budget for irrigation reached its peak in this period, with around ten million guilders per year. The number of engineers employed by the Department of Public Works exceeded 200 in the early 1920s, and reached a maximum of 263 in 1930. Irrigation design procedures in the 1920s were not very different from those in the 1890s, although the formulas and artefacts had changed. The development of hydraulic laboratories in which designs could be tested brought a new dimension to the design process, even if irrigation practice remained a determining factor in the engineering community. The Romijn weir, mentioned above, which dated from the early 1930s, belongs to this period.

\section{Discharge measurement}

Of course, while Dutch engineers had measured water long before 1930, measuring it in the Indies only began in the early nineteenth century. ${ }^{20}$ Most common were the Cipoletti and Thomson measuring structures until well into the twentieth century (figure 3). These devices are accurate and easily relocated, but are sensitive to silting and require a relatively large energy head. They were usually used if flows to the sugar cane fields had to be determined. In most cases the Cipoletti weirs were placed in the canal downstream of the intake. The head loss of the Cipoletti weir added to the existing head loss of the intake structure. It is not surprising then that engineers did not use structures at all in many irrigation systems; instead, they measured the velocity of the flow with a floating device in a straight canal section. By multiplying velocity and the surface of the canal profile, the discharge was determined. Both editions of the irrigation design handbook of Van Maanen include descriptions of floaters. ${ }^{21}$ Floaters required a relatively high labour input; in addition, there was a regular need to redefine the canal profile. The Pekalen system represented development of one of the first permanent control structures to discharge and measure water from secondary into tertiary canals (which is very similar to the modern American constant head orifice). Although it was never applied again, for the first time in the East Indies it combined the ability to discharge and measure water in one structure. The introduction of the Venturimeter was the first breakthrough in standardising discharge measurement structures in the East Indies. Dutch irrigation engineer 
Begemann introduced the Venturi structure in the East Indies in $1923 .{ }^{22}$ The Venturis became quite popular on Java, as they combined discharge and measurement in one structure; furthermore, a Venturi structure was accurate and required only a small head loss. Its popularity did not mean that new solutions were no longer sought, because the Venturi structure had two major drawbacks that were directly related to Javanese irrigation circumstances. First, it had a small measuring range: the structure could only measure a relatively small range of flows accurately. This small range was a problem on Java, with its great differences in water flows and requirements between East and West Monsoons. For Venturis the range was even more problematic, as readings were in millimetres (rather than the centimetres of other devices). To overcome its small measuring range, the possibility of constructing two small Venturis next to one another (rather than using one bigger one) was discussed. This allowed for closing one of the structures when low discharges were passing through. ${ }^{23}$ Such a solution provided satisfactory results, but it also made the structure more expensive. The second disadvantage with Venturis received more attention: a Venturimeter is not modular; the water flow through the structure depends on the tail (or downstream) water level. In other words, activities below the structure influence the flow.

The fact that interested parties (farmers and sugar factories) could potentially influence the use of measurement devices was not acceptable. A metal flap with its rotating point close to the bottom of the canal at the tail of the Venturi was proposed. Experiments in controlled laboratory circumstances showed that constructing the flap did improve the modularity of the structure. The flap was moved with a chain. This construction had only been applied to smaller Venturis, as the full water load on the chain would probably become too high for bigger ones. Other disadvantages included high maintenance requirements (with a rotating point under water) and the possibility that the Javanese farmers would manipulate the flap with the chain. Another potential improvement of the Venturi was better received, however: engineer Verwoerd proposed providing the Venturi with an overflow gate at the downstream side (figure 4). ${ }^{25}$ The gate had two parts: the lower part (a flat gate) could be opened to flush sediments; the upper part (which included a broad crested weir) was used to regulate the flow. Using the overflow gate, however, made the complete Venturi meter obsolete, because the overflow gates enable measuring the flows at the same time. This weir promised to provide an improved measuring range with lower head loss. Immediately after the article appeared, tests were conducted in the Semarang hydraulic laboratory and the Demak irrigation area close by. ${ }^{26}$ In 1932 Romijn presented the results of these tests using the overflow structure proposed by Verwoerd (although Romijn does not mention Verwoerd). ${ }^{27}$ The structure was generally considered the answer to the most important design demands for a new structure: it could discharge and measure water, had 
a small head loss and good sensitivity, it was relatively easy to construct and easy to manage. An additional advantage was that even in situations in which upstream and downstream water levels were almost equal (a drowned situation), the structure functioned quite well. In practice this meant that downstream effects on water levels had little influence on the structure's discharge, which makes it semi-modular. In irrigation systems of the late 1930s, Romijn weirs were the standard division structure, ${ }^{28}$ and their excellent performance with respect to management needs in the Netherlands East Indies was beyond doubt. ${ }^{29}$ The Romijn weir has become one of the symbols of Dutch irrigation technology, and has made the name of its researcher, Romijn, famous, while the person who proposed it, Verwoerd, has been forgotten.

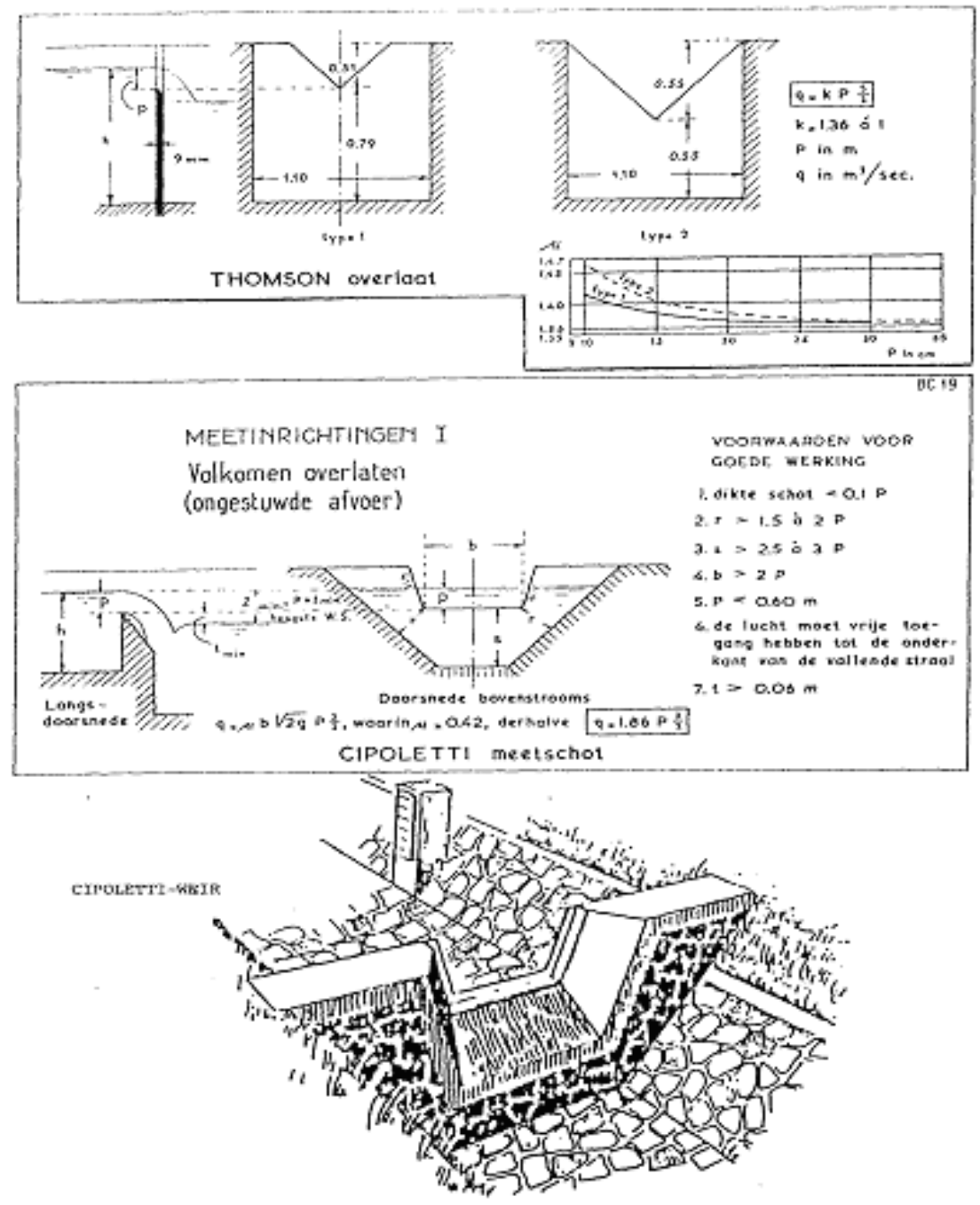

Figure 3 Cipoletti and Thomson structures ${ }^{24}$ 


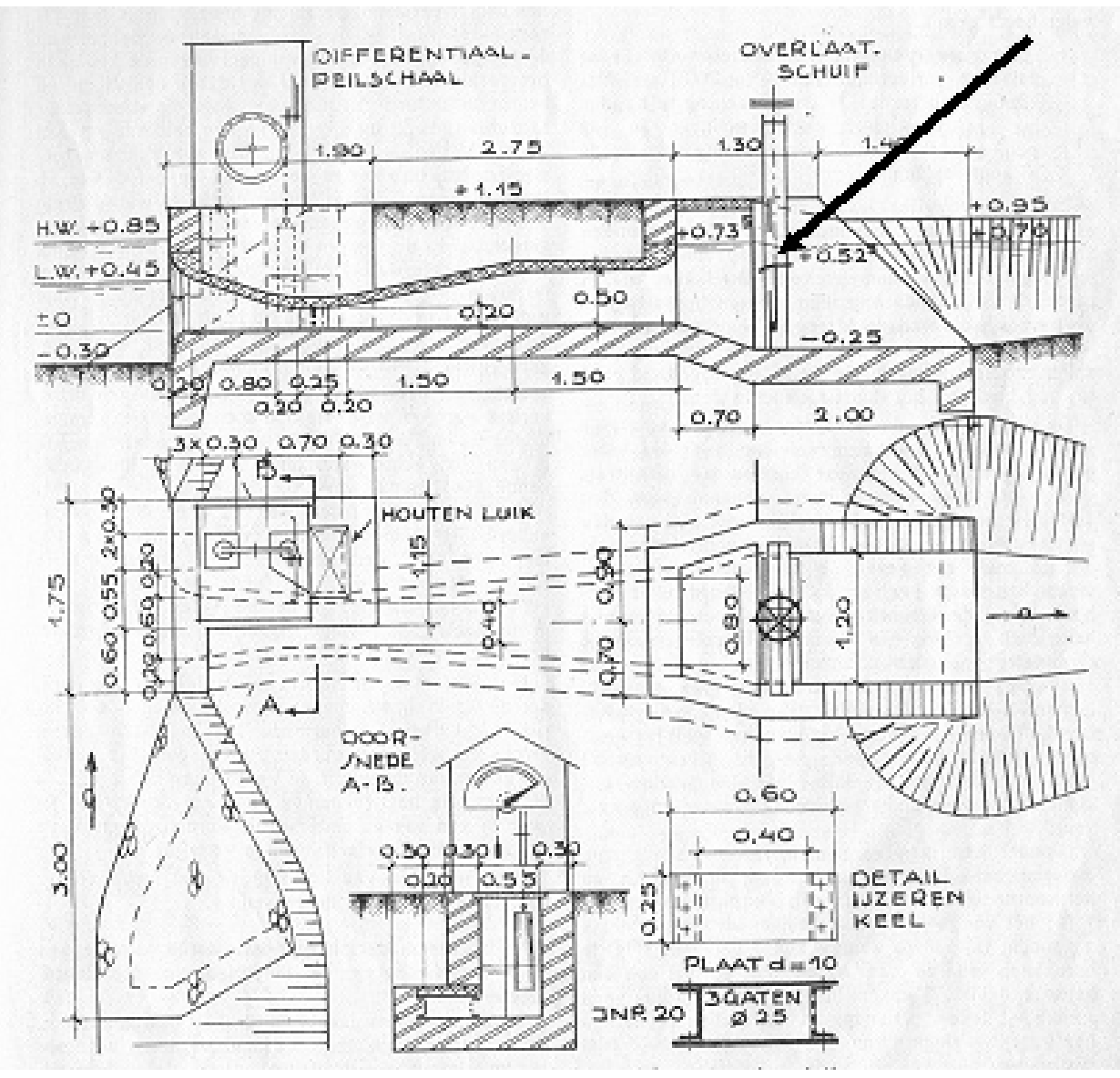

Figure 4 The overflow weir attached to the Venturi ${ }^{30}$

\section{Regime development}

The economic recession of the late 1920s and early 1930s and the growing nationalistic sentiments on Java stimulated government attention to irrigation development, as irrigation helped provide security for food production, and thus enhanced social stability. The political and management context changed somewhat when irrigation works became the responsibility of the Provincial Public Works Departments. These provincial departments were the result of colonial decentralisation policies. Three provinces were established on Java, each with its own Public Works Department. In 1936 the first General Water Regulation for Java was established, which was basically a copy of the Pemali regulation. As a result of colonial irrigation policies, independent Indonesia had 1.3 million hectares of land irrigated by engineering systems on Java in 1950. Although this was a considerable achievement, it was less than 
half of the 3,3 million hectares of land used for irrigated rice farming on Java in the same year. Since achieving independence, the population of Java has increased from 45 to more than 110 million today (about 220 million for Indonesia). At the same time, wet rice farming was extended. Although civil engineering systems covered an ever-increasing part of the agricultural lands under irrigation, farmers' systems remained responsible for a substantial portion. Many of the colonial irrigation systems still exist today. This short overview reveals that in the general process of irrigation development at least three distinct but related sub-processes can be distinguished: 1 a technical development process, which includes design procedures and routines and the infrastructure resulting from them; 2 a political process, which includes the goals of irrigation and budgetary issues; and 3 a process of professionalisation related to state formation, in which the engineers managed to empower themselves.

I have discussed the first process, using the political developments (and to a lesser extent the professionalisation process) as context. The regime categories I use reflect this approach: the political discourse on irrigation focuses on guiding principles and promises/expectations; these general categories are translated into design requirements, which in turn need to be met by applying design tools and artefacts, the major technical categories.

Our next concern is to understand the social construction process in which the Netherlands East Indies irrigation regime(s) have come about. I touched on the distinction above between the situations in the 1830s and the 1940s: the first part deals with how to understand the transformation from 1830 (no irrigation regime whatsoever) to 1940 (well established irrigation regime); the second part deals with whether or not this transformation process involved interim regime changes before the final one in 1940. The Dutch irrigation approach did not develop all at once between 1830 and 1940. For the design triangle, it could be argued, the guiding principles and the design requirements were formulated relatively early, whereas the design tools and artefacts showed a more continuous development over time. 'Closure' of the principles and requirements occurred much earlier than 'closure' for tools and artefacts. Along with the new expenditures, there was a new wave of broad political debate in the first years of the twentieth century that included extensive discussions on welfare policies and water distribution. The relationship between sugar cane and rice remained an important issue up to the 1930s; nevertheless, their co-existence was not itself discussed. Thus, while the political debate may have changed, with new social groups entering the arena (such as the agricultural engineers after 1900), politics had already exerted its influence. The agricultural context of Dutch colonial irrigation (translated into guiding principles) had been set with the Cultivation System: commercial and food crops needed to be irrigated through the same irrigation infrastructure. The new generation of irrigation projects 
on Java of the 1920s did not differ fundamentally from the generation before: the new systems had been designed along the same rationale and procedures as their ancestors. Changes in the elements (particularly artefacts and the design formula) had not altered the design rationale and procedures already established in 1900. In a way, the second generation projects realised the basic principles of colonial water management through application of new hydraulic insights and artefacts. Thus, the irrigation regime development process in the Netherlands East Indies should not be regarded as one that included regime shift.

Ravesteijn, however, argues that

in the irrigation development in colonial Java various technological regimes can be distinguished. ${ }^{31}$

He focuses especially on the transition from the 'technical irrigation regime' (a tradition that emerged in 1885) to the 'technical-agricultural irrigation regime' (which emerged around 1920).

In reality, the Technical-Agricultural Irrigation Regime did not dispel the Technical Irrigation Regime, rather it absorbed it. ${ }^{32}$

'Absorbing' seems to be more continuous than 'transition'; indeed, the author occasionally stresses a gradual transformation. My research also supports the idea of gradual transformation. In the conclusion to Ravesteijn's article, however, the differences between the two regimes are again stressed. In 1920, when colonial irrigation activities recommenced after World War I,

a new generation of irrigation projects that differed in main outline from what had gone before . . . (developed). ${ }^{33}$

Ravesteijn argues that these new systems were different in several aspects: irrigation management, agricultural aspects of projects, reservoir construction technology, the step-wise approach to the creation of irrigation works, and the development of laboratory facilities. ${ }^{34}$ Figure 5 shows our two points of view. I would argue that the differences between the 'technical' and 'technical-agricultural' regimes are not significant enough to support regime shift. What I would call fundamental design approaches, mainly those resulting from the presence of sugar cane and rice, were similar in the two 'regimes'. Clearly, certain elements have changed, especially the artefacts and the design formula used in the design process. But these changes have not affected the rationale and procedures already established around 1900. Explanations of transformations in the design process and its results need to be couched in terms such as 'refinement' or 'detailing' (terms also used by Ravesteijn), not in 'transition' or 'change'. For the regime triangle, the guiding principles and promises/expectations of colonial irrigation have not profoundly changed. While I do define one change below, I conclude that the 'rules vital for the continued existence of a technological regime ${ }^{35}$ did not change once they had been established for Dutch colonial irrigation. I agree with Van de Poel when he argues that a: 
technological regime is transformed if one or more of its core or constitutive rules changes. It is historically contingent which rules are constitutive for a specific technological regime. ${ }^{36}$

It is reasonable to acknowledge a shift from one technological regime to another only if there is a significant difference in most of the guiding principles and promises/expectations, along with some of the requirements.
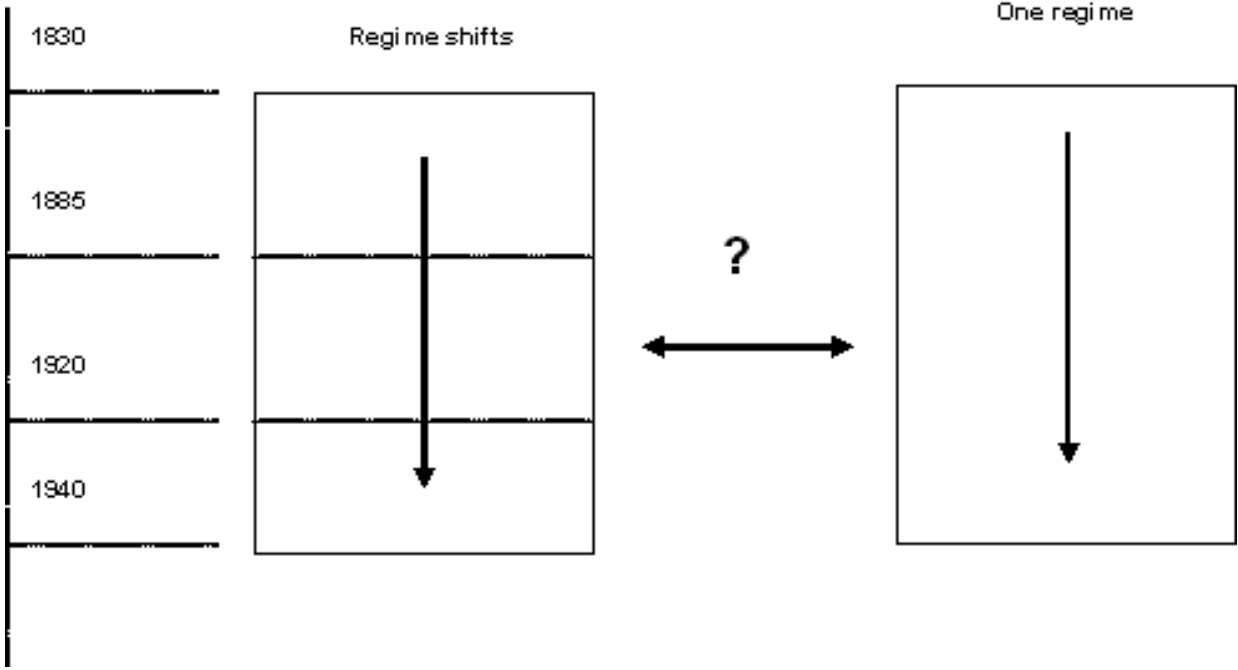

Figure 5 Two regime development points of view

One important explanation for Ravesteijn's and my different positions on regime development is in our conceptualisations of the regime concept. Ravesteijn's concept of regimes is broader than mine: I focus on the design activities of the irrigation engineers, who sought ways to translate the results of discussions on irrigation in colonial circles into an irrigation infrastructure. Ravesteijn attempts to distinguish patterns within these broader debates and to link these patterns to technical developments in colonial irrigation. One clear example that helps elucidate our different positions is the increasingly important influence of agricultural engineers in the colonial state. In an emancipation process similar to that of the civil engineers, the agricultural engineers gained positions within the colonial apparatus, including those related to irrigation. I do not view the growing institutional influence of the technological regime as being sufficient reason to distinguish a change in regime. To warrant such a change, there should be a change in design principles or practices to define changes. As for the agricultural aspects of projects, the sugar cane and rice tandem influenced the debates throughout the entire colonial period, but the procedures to deal with the problems were set around 1880. These procedures have been applied in systems design in the 1920s, 
even when sugar cane cultivation was not feasible from an agricultural perspective.

Similarly, I argue that for irrigation management, an issue intimately related to the cropping tandem, the final contours of water management regulations, established in the 1930s, are really copies of contours set around 1900. The setting in which new artefacts were introduced was not fundamentally different. The Romijn weir relates directly to the first discourses on water distribution on Java, even though its final shape was tested in the hydraulic laboratory of Semarang in the early 1920s. The outcomes of these debates have been influenced by changes in the colonial context (policies, economics). Yet, the basic guiding principles of Dutch colonial irrigation and its related design practice have not been contested in these debates. Therefore, I conclude that the development process of the Dutch colonial irrigation regime cannot be described as a series of different regimes. Not being able to distinguish different regimes does not imply that it is not possible to distinguish several phases in the regime development process in the Netherlands East Indies. Although I would argue that these phases cannot be seen as representing shifts or changes in direction of the regime, I do think it is possible to recognise a certain pattern in the regime development process. I argued above that the 'higher level rules' (guiding principles and promises/expectations) were developed earlier than 'lower level rules'. Here I provide some of the specifics. For example, illustrative is the statement that

periodization is clearly a function of the present: as one looks back from further away in time, the pioneering phase was longer and the distinctions more general. ${ }^{37}$

Indeed, I am also part of the law of the distant observer, since I distinguish between two phases of the development process in the Netherlands East Indies irrigation regime (Figure 6 shows a graphic view of these phases between 1870 and 1940). The phase between 1870 and 1910 can be best understood as the 'formation phase' of the regime, when the guiding principles, promises/expectations, and most of the design criteria took shape. The focus in this phase was on developing principles for irrigation design. The phase between 1910 and 1940 can best be understood as the 'elaboration phase' of the regime, when the tools and artefacts to translate the general rules into physical infrastructure were defined. The focus in this phase was on perfecting the tools and artefacts applied in irrigation design. While it is difficult to pinpoint the exact year that separates each phase, the period between 1900 and 1910 can be viewed as a turning point.

It is clear that in the early period the higher level rules and the most important design criteria were defined, whereas the later phase focused on the tools and artefacts. The key elements for colonial irrigation, culminating in the requirements for water management and system design, were established in 1900. The only element that should be 
defined as new is that irrigation activities of the late colonial state (that is, after 1920) focused on developing empty areas through irrigation infrastructure for settlers. These settlement schemes in West Java and other islands differed to some extent from the early systems, which were mainly located in East and Central Java. The co-existence of sugar cane and rice was true for these regions of early colonial irrigation development on Java. The presence of sugar factories and its associated emphasis on water use and management was a strong motive for colonial rule to intervene in irrigation development in the first place. In the later colonial systems sugar cane was not yet cultivated (nor was it even expected in the future); yet the potential presence of sugar cane was accommodated in the design. I would argue that the regime rules constructed in the formative phase mainly focused on East and Central Java, whereas the elaboration phase, in which the central activity was to provide further detail for the technological framework, focused on West Java. Thus, the guiding principles of Dutch colonial irrigation, developed in the early days of colonial irrigation policies, were based on systems that were not generally representative of the newer systems after 1920, neither in scale nor topography. The shift from the early (generally smaller) systems of East and Central Java to the (larger) settlement schemes did change the practical context of regime elaboration, but it did not change the guiding principles. Nevertheless, at the end of Dutch colonial rule, the technological vision of the irrigation engineers became separate from its original guiding principles; these original principles were not ignored, but were well integrated, or even hidden in the technological framework.

The irrigation regime development process described in this paper (or the innovation/transformation pattern of the Netherlands East Indies irrigation regime) can be understood as a mission-oriented innovation pattern, which is defined by Van de Poel $(2003 ; 55)$ as a pattern in which 'innovations derive from a mission formulated by a powerful actor acting as principal for the artefacts designed. Such missions define a framework within which innovations are accomplished.' In such a mission-oriented innovation pattern, the main carriers of innovation/transformation are governmental agencies, and the areas in which such a pattern is to be expected include defence, energy, communications, and transport. In the Netherlands East Indies, the powerful principal actor is the colonial state - and this state should be understood as resulting from a process of social construction, at least insofar as its irrigation related policies are concerned. Several social groups, including civil engineers, civil servants, and agricultural engineers (as insiders in the state regime), and the principals in the sugar cane industry (as important outsiders) debated desired irrigation developments. I argue that the civil engineers became the dominant group early on (that is, around 1890) in this discourse. Although the civil servants were the dominant group, irrigation was not their core business. They were involved in some important regime 
elements, such as establishing water regulations, but their importance decreased steadily over time. Agricultural engineers entered the discourse to some extent after 1900, when the guiding principles were already defined. While they were active in Javanese agriculture, they had little influence on regime elements as defined in this paper (which mainly focuses on irrigation design).

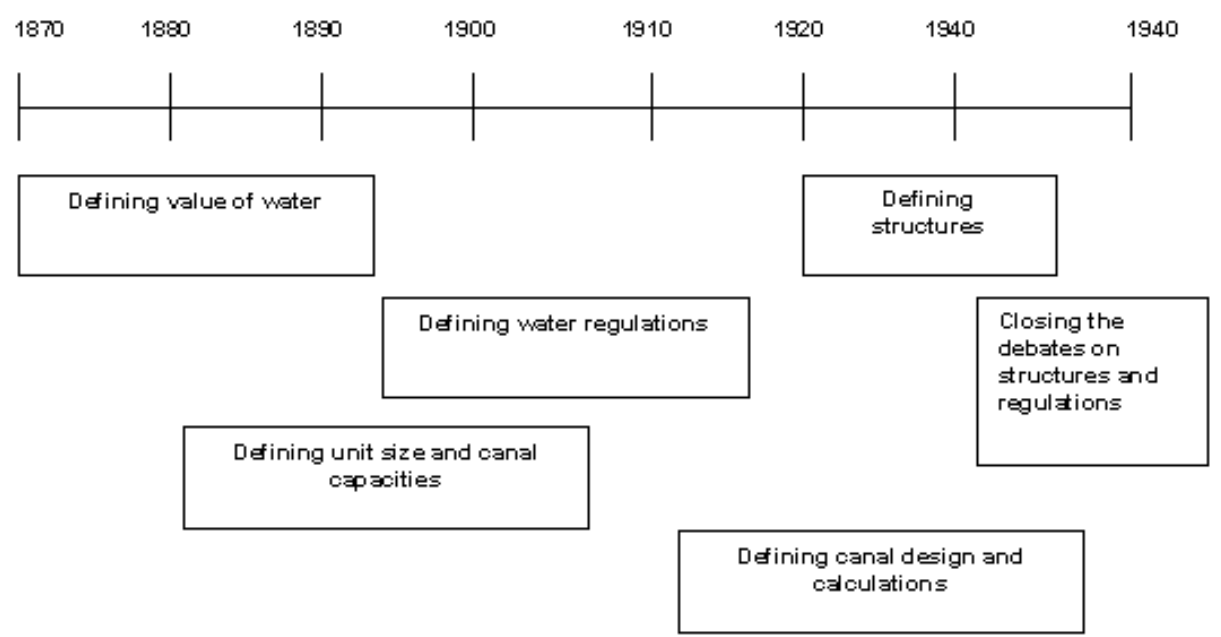

Defining peak discharge calculation

\section{Formation phase ............... Elaboration phase}

Figure 6 Regime phases in the Netherlands East Indies ${ }^{38}$

While it is expected that the engineers would have been the logical social group to determine regime development for the technical aspects of irrigation development (other examples are defining layout of systems and applying design tools), they exercised a strong influence on the "nontechnical' regime aspects, as well. The final General Water Regulation for Java in 1936 (the Pemali regulation) is a case in point. Of course, the Pemali regulation and the many others discussed were not exclusively engineering products. Within the engineering community, opinion was divided about the best water regulation; moreover, civil servants were usually involved in the development of regulations. Nevertheless, it was the responsibility of irrigation engineers (and lower staff members) to shape water distribution practices in the irrigation systems within the context of these regulations. The key position of the engineers within colonial regime development is partly explained by the mission innovation 
pattern: if in such patterns the relationship between main actor and innovators is close, the

\begin{abstract}
design of the technology will be guided by the existing mission in a more direct sense, i.e. via direct hierarchical relations. Such a situation, for example, existed at least until recently in the Dutch infrastructure section. In this sector, governmental agencies - pre-eminently the Rijkswaterstaat - act as client/principal, designer, researcher and regulator. . . R\&D and design activities, to an important extent, take place within the same organisation that formulates missions for technical projects. ${ }^{39}$
\end{abstract}

Another factor that explains the relatively important role of the engineers is in the phasing of the regime development process. For the phasing and regime hierarchy, I would argue that the guiding principles ('core rules, i.e. rules that are vital for the continued existence of a technological regime ${ }^{24}$ ) were defined before most of the rules for tools and artefacts ('peripheral rules. . . not constitutive for a technological regime ${ }^{41}$ (although they are still important $t^{42}$ ). These core rules were developed in a period when the engineers were one of the most influential social groups in the colonial state. The years from 1870 to 1900 may well have been the most successful period for engineers: they had power, influence, and independence. The most important core element (in the technological tradition, the guiding principle) was the presence of sugar cane and rice in the same irrigated area. This was a direct result of the colonial economic optimisation approach, which was based on productivity per unit of land. Such an approach should ensure that the benefits of irrigation development would accrue to the colony as a whole, not just a small group in colonial society. Using the guiding principles they helped establish, the engineers continually looked for and proposed new applications to regulate and measure discharge within the irrigation system; final closure only came in the 1930s.

There was a pause in this development between 1910 and 1920, with World War I as a clear demarcation. From 1920 to 1940 there were renewed irrigation activities. The internal decision-making process of the Department of Public Works and its representatives checked the design process; proposals made by designers were required to meet the standards, unless there were good reasons not to. Internal documents, or design guidelines, produced within the engineering community played a very important role in maintaining continuity, and these internal guidelines had a considerable influence on the direction Dutch colonial irrigation developed in the East Indies irrigation design process. The guidelines stored the information available to the design engineering network. The continuous relevance of colonial design rules in Indonesian irrigation practice and Delft irrigation education shows the essential role of storage in the existence of networks representing technological traditions, as it permits time-space distantiation: older design guidelines still influence later designers. Before guidelines can be produced, the design rules to be included must be well known, tested, and accepted. In the East Indies the 
proof of the pudding was in the eating. Applications that had been shown to work in a real-life irrigation system were potential candidates for use as a guideline from the Department of Public Works. Irrigation practice was the determining factor in the selection of discharge measurement structures. Begemann proposed the Venturi structure based on his own experiences in a Javanese irrigation system, and it became a success. Problems raised in practice, especially in the modular behaviour of the structure, however, finally resulted in the Romijn weir.

A similar story emphasising the central role of practice is true for water regulations: many regulations existed on Java that were usually designed by local and temporary coalitions of participants, including engineers, local governmental authorities, and occasionally others. The engineers, in charge of daily activities for the irrigation system, were the impetus behind most regulations. In 1936, when the legal base for water regulations was finally approved, the Pemali regulation (mainly developed by civil engineers) was extended to the entire area of Java. These findings accord with Geels (2002), who concludes that

\footnotetext{
novelties first in [sic] emerge in technological niches. . . The novelties often contribute to solving problems in the existing regime. The interpretation of the functionality of novelties often occurs with categories from the existing regimes. ${ }^{43}$
}

The irrigation engineers' niche was the practice of their irrigation systems: developments proven in or based on practice were selected. The Romijn weir was originally proposed as an improvement to a practical problem of the Venturi structure. When the broad-crested weir proposed by Verwoerd was tested against the regime requirements (adjustability, measurement, low head loss), it immediately became the new solution.

\section{Regime continuity}

Unlike World War I, which only put a temporary halt to expenditures, World War II clearly demarcates a difference in irrigation regimes: suddenly the stable working practice that had existed in the East Indies disappeared. Following World War II, new political realities necessitated a major shift for the Dutch irrigation regime. Indonesia was no longer the main context. Indonesia and the Netherlands were not unique in the disruption of colonial realities, for in the 20 years following the end of World War II most colonies had gained their independence (and were redefined as 'developing countries'). In this new reality Dutch irrigation engineers began to work in areas beyond what had been the Dutch colonial empire. The first generation was able to benefit directly from its experience in the Indies, while the second generation benefited from that experience through their education and training in Delft. As Geels argues, 'diffusion and breakthrough of new technologies depends on wider 
external circumstances..., ${ }^{44}$ and the post-War situation provided several 'windows of opportunity'. ${ }^{45}$ Dutch engineers began to work in other tropical regions, and engineers from different countries operated in an independent Indonesia.

The windows of opportunity, however, remained closed for a long time in the irrigation education program in Delft. Although the new working realities for Dutch irrigation (and hydropower) engineers were recognised and explicitly taken into account to defend continuation of the Delft irrigation and hydropower programs, the course materials suggest that irrigation engineering in Delft was based on the application of several design principles developed in the Netherlands East Indies.

Professor Haringhuizen, who held the irrigation chair in Delft from 1919 to 1938, must have been the founding father of Delft irrigation education (with his predecessors having created the necessary place). He was the first irrigation professor in Delft to develop written course materials on a larger scale than simple handouts. ${ }^{46}$ Haringhuizen's successor, S.H.A. Begemann, continued this pattern by providing lecture notes. ${ }^{47}$ Haringhuizen's and Begemann's notes were based largely on the Netherlands East Indies, since other regions were scarcely mentioned. From 1954 onwards, Professor Berkhout was responsible for three courses on irrigation. ${ }^{48}$ These included: F17 (a short course on irrigation), F18 (the regular extensive irrigation course), and F19 (a course on major structures and reservoirs, which included most of the statistical materials). Course F17 dealt with most of the standard elements that had been included in Begemann's lecture notes. These notes contained about 110 pages, as did the F17 notes, and the two are very similar in content, although there were some differences, for such as the section on discharge measurement. Berkhout's materials include much more information on Cipoletti's and Thomson's weirs, but there is less attention to Venturi's and Crump de Gruyter's technology. Professor Schoemaker, who followed Berkhout in 1967, continued to use his lecture notes. Although he kept the lecture notes, Schoemaker developed new course materials; he produced a number of (sometimes extensive) monographs on several subjects, including canal design. These additional documents were not part of the final examination, however, but were available to the students for use in their professional practice, if needed. It is likely that only very few students actually studied the additional materials.

All civil engineering students in Delft specialising in irrigation engineering had to develop a final design for an irrigation system. Fortunately, I have been able to retrace several student design reports from the Delft irrigation department archives. The designs are from the period 1937 to 1980, with most having been done after 1954. About two-thirds of the total deal with Indonesia (96 of 149), with most of them taken directly from systems developed during the colonial period (see the discussion below). More than half the designs dealing with areas outside Indonesia concern two 
African countries, Ethiopia and Tanzania (34 of 53); it is probably not a coincidence that these designs were for irrigation systems for sugar cane cultivation (although the designs for Ethiopia do include some other crops). All design tasks require similar activities; they must include: (1) the main layout of the irrigation system, including the planning of units, (2) calculations for a number of canals, including drawings of length profiles, and (3) details for one or two hydraulic structures, usually the intake structure and the sand trap.

An analysis of these student designs shows that they all include typical elements from the East Indies. In almost every design the Romijn weir is selected as the discharge measurement structure. What may have been self-evident for Indonesian designs (and, probably not even surprising for the modern researcher) is also self-evident for non-Indonesian subjects: Delft students based their designs of irrigation systems on the East Indies model. In only three of the designs was a particular reason given for the choice of the Romijn weir. Most students selected the Romijn weir without any discussion: the structures are not usually detailed, but are included in the design reports because their head losses influence the water level needed at the intake. In the three cases where the students did discuss the appropriateness of the Romijn weir, the justification is quite different. One student selected Romijn weirs for most off-takes in his Syrian system. While he recognised it would have been possible to choose a different type of structure for one off-take with considerable available head loss, he decided to select the Romijn weir for reasons of standardisation. In a design for East Pakistan (Bangladesh), one student used Romijn weirs for small off-takes and Venturis for larger ones. Student Visser, however, who designed an irrigation system for Ethiopia, decided to use a Parshall flume; this choice was also influenced by the fact 'that it is useful to gain some experience in designing these measuring devices of American origin. ${ }^{49}$ Apparently, using a structure that was different from those used in the East Indies context needed more justification than did the usual Romijn weir.

Most designs for a final paper include the same frame-based elements, and most of these elements were used without any further justification. These designs all employed techniques that had been socially constructed between 1830 and 1940 under the Dutch colonial irrigation regime. The regime was constructed as part of a process in which irrigation practice was the main determining context for transformations. After Indonesian independence, however, the direct link between irrigation practice and regime disappeared; the regime lost its clear locus. Nevertheless, Delft education remained strongly rooted in the East Indies regime. In the 1980s, however, irrigation education in Delft severed its ties to the Netherlands East Indies technological regime, allying itself with the international diversity of current irrigation practice. Yet, even though the Netherlands 
East Indies influence is still recognisable, the colonial elements are no longer prescriptive, but are seen as only possible examples to follow.

\section{Notes}

1. Boiten, W. (1987), De Hobrad stuw. Regelen en meten van debieten, PT/C 1(41), pp. 51-57.

2. From http://www.bergschenhoek-ct.com/NL/bct/pdf/rowatrvs/rowat overstortschuiven.pdf on April 28, 2005.

3. This paper is based on Ertsen (2005), Prescribing Perfection. Emergence of an engineering irrigation design approach in the Netherlands East Indies and its legacy, 1830-1990. Ph.D. thesis Delft University of Technology.

4. Constant II, E.W. (1980), The Origins of the Turbojet Revolution, Johns Hopkins, Baltimore; p. 10. Not only hardware is included (e.g. artefacts), but the software as well (e.g. management principles).

5. Constant II (1980).

6. Poel, I. van de (2003), The transformation of technological regimes, Research Policy 32, pp. 49-68; Poel, I. van de (1998), Changing technologies. A comparative study of eight processes of transformation of technological regimes, Twente University Press, Enschede.

7. Poel, van de (2003; p. 49).

8. Picon, A. (2004), Engineers and engineering history: Problems and perspectives, History and Technology 20(4) 421-436; p. 424.

9. Poel, van de (1998); Poel, van de (2002); Geels, F.W. (2002), Understanding the dynamics of technological transitions. A co-evolutionary and socio-technical analysis, Ph.D. thesis Twente University.

10. Geels (2002).

11. Giddens, A. (1979), Central problems in social theory: Action, structure and contradiction in social analysis, Contemporary social theory, MacMillan, London; p. 216.

12. Giddens, (1979), p. 64.

13. Giddens, (1979), p. 64.

14. Poel, van de (1998; 2002).

15. Poel, van de (1998), p. 16.

16. From Poel van de Poel (1998), p. 17.

17. Based on Ertsen (2005).

18. The cropping cycle of sugar cane was three years: first year planting, second and third year maturing, and several times harvesting.

19. The comparison with British India is illustrative: the British were looking for a structure that could deliver a fixed (relative or absolute) amount, but they were not interested in regulating this on a short-term basis. See, for example, Boldin, A., Mollinga, P.P. and Van Straaten, K. (1995), Modules for modernisation: Colonial irrigation in India and the technological dimension of agrarian change, Journal of Development Studies, 31(6) 805-844; Ertsen, M.W. (2002), Irrigation traditions, 
roots of modern irrigation knowledge, International Journal of Technology, Policy and Management, 2(4) pp. 387-406.

20. Chapter 3 of Ertsen (2005) discusses these in detail.

21. Maanen, Th.D. van (1931) Irrigatie in Nederlandsch-Indië. Een handleiding bij het ontwerpen van irrigatiewerken ten dienste van studeerenden en practici, Boekhandel Visser and Co, Batavia (first edition, 1924).

22. Begeman, S.H.A. (1924), Toepassing van Venturimeters voor bevloeiïngsleidingen met gebruik van differentiaal peilschalen, De Waterstaatsingenieur 12(11) pp. 325-330.

23. Verwoerd, A.L. (1930), Ontwerp van een module venturimeterinlaatsluis met groot meetbereik, De Waterstaatsingenieur 18(4).

24. Lecture notes on irrigation CT4410 (1997), Delft University of Technology.

25. Verwoerd, A.L. (1930), Ontwerp van een module venturimeterinlaatsluis met groot meetbereik, De Waterstaatsingenieur 18(4).

26. National Archives, The Hague, the Netherlands; Collection Haringhuizen-Schoemaker; no. 2.22.07; Inventaris van een verzameling stukken betreffende openbare werken in Nederlands-Indië en Suriname afkomstig van het Instituut voor Waterbouwkunde in Delft over de jaren 1872-1970; inventory number 53; Meetinrichtingen in de Irrigatieafdeling Pemali-Tjomal (probably around 1930); Romijn 1931 Verslag 1931 over de ervaring, opgedaan bij de exploitatie van meetinrichtingen in de Sectie Demak der Provinciale Irrigatieafdeeling "Serang".

27. Romijn, D.G. (1932), Een regelbare meetoverlaat als tertiaire aftapsluis, De Waterstaatsingenieur 20(9).

28. Other engineers discussed certain individual features of the Romijn weir, such as the reading mechanism (Hens, E.E. (1934), De aanwijsinrichting van den regelbaren meetoverlaat, De Ingenieur in Nederlands-Indië 1(12) VI, 129-131), or the slope of the weir blade (Vlugter, H. (1940), De regelbare meetoverlaat, De Ingenieur in NederlandsIndië 7(10) II, pp. 157-164).

29. Steneker, P. Ph. (1935), Overzicht van met verschillende meetinrichtingen verkregen uitkomsten, De Ingenieur in Nederlands-Indië 2(6) VI, p. 83-85.

30. Romijn, D.G. (1938), Meetsluizen ten behoeve van irrigatiewerken. Handleiding voor het ontwerpen en exploiteeren, ten dienste van practici en studeerenden; p. 19.

31. Ravesteijn, W. (2002), Irrigation development in colonial Java: The history of the Solo Valley works from a technological regime perspective, International Journal of Technology, Policy and Management, 2(4) pp. 361-386; p. 363.

32. Ravesteijn (2002), p. 378.

33. Ravesteijn (2002), p. 383.

34. Ravesteijn (2002), p. 382.

35. Poel, van de (2003), p. 52.

36. Poel, van de (2003), p. 52.

37. Ravesteijn, W. (1997), De zegenrijke heeren der wateren. Irrigatie en staat op Java, 1832-1942, Delft University Press, Delft; p. 364.

38. Ertsen (2005).

39. Poel, van de (2003), p. 55; note 11; emphasis in original.

40. Poel, van de (2003), p. 52. 


\section{Ertsen}

41. Poel, van de (2003), p. 52

42. See for a much more detailed analysis, Poel, van de (1998).

43. Geels (2002), p. 322.

44. Geels (2002), p. 323.

45. Geels (2002), p. 323.

46. National Archives; collection 2.22.07; Inventory number 148-153, College dictaten van colleges van prof. ir. J. Haringhuizen.

47. Archive Section Land and Water Management.

48. Archive Section Land and Water Management.

49. Final paper, design Visser (1959), p. 33; Archive Section Land and Water Management. 